\title{
Aproximación al estudio de la interjección en el árabe dialectal de Egipto
}

\section{Approximation to the Study of the Interjection in Egyptian Dialectal Arabic}

\author{
Saad MOHAMED SAAD \\ Departamento de Filología y Traducción \\ Universidad Pablo de Olavide de Sevilla \\ smohsaa@upo.es
}

Recibido: 15 de abril de 2014

Aceptado: 23 de junio de 2014

\section{RESUMEN}

Nuestro objetivo aquí es analizar el uso de las interjecciones en el árabe dialectal de Egipto, prestando una especial atención a las de carácter emotivo. Para ello, empezamos por estudiar la naturaleza lingüística de las interjecciones, llegando a la conclusión de que su contenido semántico es de carácter puramente procedimental y su significado exacto depende enormemente del contexto y/o la situación del discurso. Analizando las posibilidades combinatorias de las interjecciones, concluimos que son sintagmas que se muestran reacios a la transposición o a cualquier otro mecanismo de enlace que pueda afectar a su categoría sintáctica de entrada. Nos centramos también en el análisis de los valores semánticos con los que se emplean estos elementos en el dialecto que nos incumbe, detectando la existencia de dos mecanismos básicos de creación de nuevas unidades: la lexicalización de expresiones de contenido originalmente vocativo o de carácter religioso.

Palabras clave: interjección, árabe dialectal de Egipto.

\begin{abstract}
Our aim in this issue is to analyze the use of interjections in the dialectal Arabic of Egypt, giving a special attention to those of emotive sense. We begin studying the linguistic nature of interjections and conclude that they are always used to convey a vague sense, because of the procedural nature that they semantically have. Analyzing the combinatorial possibilities of interjections, we can affirm that they are autonomous sequences that do not accept transposition or any other mechanism of link that could change their original syntactic category. Finally we centre upon the semantic values with which these elements are used in Egyptian Arabic and detect the existence of two basic mechanisms of creation of new interjections: the lexicalization of expressions of original vocative content or religious sense.
\end{abstract}

Keywords: interjection, dialectal Arabic of Egypt.

SUMARIO: 1. Naturaleza lingüística de la interjección, 2. Función pragmática de los elementos interjectivos, 3. Sintaxis de los elementos interjectivos, 4. Semántica de las unidades interjectivas, 4.1. Interjecciones propias, 4.2. Interjecciones impropias, 5. Conclusiones. 


\section{NATURALEZA LINGÜÍSTICA DE LA INTERJECCIÓN}

La interjección ha sido siempre un elemento polémico dentro de los estudios lingüísticos. De entrada, ha habido opiniones que niegan la propia naturaleza lingüística de estas unidades, rechazando la idea de ver en ellas los dos planos característicos de todo signo lingüístico: un significante que se asocia a un significado convencional. Para este grupo de investigadores, las interjecciones son una especie de patocinesia, que se asemeja a los "movimientos del rostro con que nos mostramos suplicantes, tristes, alegres, soberbios, etc." lingüísticos humanos, continuación -por similitud- del grito inarticulado de los animales" ${ }^{2}$. En definitiva, las interjecciones son para ellos un conjunto de elementos que pertenecen a la categoría de los indicios, tal como se describen en los estudios de semiótica. Tampoco existe unanimidad, por otra parte, entre los que consideran los elementos interjectivos como signos convencionales, a la hora de determinar su estatuto lingüístico, debido a que "la interjección es un modelo harto deslizante y no se puede encerrar en moldes como las otras partes de la oración, pues en ella hay que tener en cuenta la inestabilidad con que el hablante la emplea”. Así, su estudio suele correr parejo a preguntas como las siguientes: ¿constituye una oración o es una parte de la misma? Y en caso de aceptarla como una parte de la oración, ¿formará una categoría sintáctica independiente, pertenecerá a la de los adverbios, será considerada acaso como una especie de partícula, etc.? ${ }^{4}$

En primer lugar, es innegable para nosotros la pertenencia de las interjecciones a la categoría del signo lingüístico, al existir en ellas "una correspondencia perceptible entre una expresión y un contenido en cada uso interjectivo", la cual no ha de ser ni idéntica ni de obligada aparición en más de una lengua. Creemos, por otro lado, que toda la controversia que en la tradición lingüística se ha suscitado en torno a la naturaleza de la interjección se debe básicamente al hecho de que se ha pensado siempre en ella como un signo formado por un significante que ha de referir ineludiblemente a una representación mental de cierto elemento que pertenece al mundo que nos rodea. Y aquí radica, precisamente, el error, puesto que no todos los signos lingüísticos poseen un significado exclusivamente conceptual, que alude a un elemento extralingüístico. Así, en un enunciado tan simple como:

\footnotetext{
${ }^{1}$ RABANALES, Ambrosio, "La somatolalia”, en Boletín de Filología (Universidad de Chile) 7 (1954-55) 355-378, 361.

${ }^{2}$ ALMELA PÉREZ, Ramón, Apuntes gramaticales sobre la interjección, Secretariado de Publicaciones de la Universidad de Murcia, Murcia 1990, 38.

${ }^{3}$ ALVAR, Manuel, “La interjección”, en Introducción a la lingüística española, M. ALVAR (dir.) (2000) vol. I, Ariel, Barcelona, 479-490, 481.

${ }^{4}$ AMEKA, Felix, "Interjections: The universal yet neglected part of speech", en Journal of Pragmatics 18 (1992) 101-118, 102-104.

${ }^{5}$ CUETO VALLVERDÚ, Natalia y María Jesús LÓPEZ BOBO, La interjección. Semántica y pragmática, Arco/Libros, Madrid 2003, 13.
} 
- Los niños volverán ahora del colegio ${ }^{6}$,

$$
\text { ـ الأو لاد هيرجعوا من المدرسة دلوقتي، }
$$

podemos distinguir dos categorías de unidades lingüísticas. La primera incluye

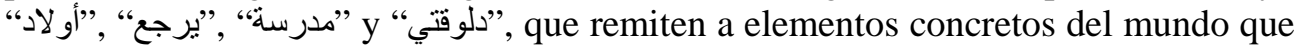
nos envuelve y constituyen, por lo tanto, una de las dos vertientes de signos fácilmente reconocibles por cualquier hablante del árabe dialectal de Egipto. Son elementos que aluden, pues, a conceptos que se corresponden a ciertas representaciones mentales. La segunda categoría de unidades está integrada, a su vez, por “ال", “\$”, y "من", así como por los elementos vinculados con el tiempo, el modo y las relaciones sintácticas entabladas dentro de la oración, respectivamente. Lo único que hacen estos últimos elementos, a diferencia de los primeros, es codificar una especie de información muy vaga y difícil de describir en términos conceptuales. Para funcionar adecuadamente tienen que estar inmersos en una situación concreta, puesto que son meras instrucciones que envía el emisor a su oyente, en relación con el modo en el que se tienen que procesar las unidades lingüísticas de la primera categoría. De esta forma, los artículos aquí usados contribuirán a identificar tanto el colegio como a los niños de los que se habla en este caso. Por su parte, el tiempo ubicará la acción del verbo en un punto dado de la cadena cronológica, partiendo siempre desde el momento de la enunciación, etc. Los elementos que pertenecen a la primera categoría de signos comportan un evidente sentido conceptual, en tanto que los de la segunda transmiten información puramente procedimental ${ }^{7}$.

Si analizamos el tipo de significado que un hablante puede comunicar mediante el uso de la interjección, nos daremos pronto cuenta de que la información que transmite es de esta segunda clase. Así, al reparar en el significado de una interjección dada, tal como, por ejemplo, “با ندامة", veremos que lo único que codifica es una suerte de sentido vago e instrucción emitida con el objetivo de que el receptor entienda que el emisor "está molesto por algo"; la fuente de su malestar se tiene que buscar entre los elementos que constituyen la situación del discurso. Solo cuando esto se produce, el significado exacto de la interjección queda precisado mediante la aplicación de los mecanismos de inferencia. De esta forma, la interjección señalada recibirá distintas interpretaciones en situaciones lingüísticas tan dispares como las siguientes:

${ }^{6}$ Tal como nos ha sugerido el Consejo de Redacción de esta Revista, intentaremos, en la medida de lo posible, traducir al español todos los ejemplos aquí presentados. Las traducciones se harán para satisfacer un único fin: facilitar la lectura y comprensión de este trabajo a los investigadores no especializados en el árabe dialectal de Egipto. Para definir lo que entendemos por esta variante de árabe, señalamos que en esta ocasión utilizamos este término para aludir a la variedad de árabe usada en la comunicación lingüística diaria, en situaciones informales, por los habitantes de cultura media de las grandes ciudades del país, especialmente El Cairo y Alejandría.

${ }^{7}$ ESCANDELL, María Victoria y Manuel LEONETTI, "Semántica conceptual / semántica procedimental”, en Actas del V Congreso de Lingüística General, Arco/Libros, Madrid 2004, 1727-1737.

${ }^{8}$ Nos basamos en este trabajo en un corpus formado por las siguientes tres obras: HAKĪM, Tawfīq al-, 'Awdat al-rūḥ, Dār al-Kitāb al-Lubnānī, Beirut, 1974 (en dos volúmenes); JAMĪSĪ, Jālid al-, Tāksī. 
1. Petición de disculpa por un descuido cometido por el hablante:

$$
\begin{aligned}
& \text { ـ فأجابت مسنطر دة: } \\
& \text { - إن ماكانش هو الو اد "عبده"... [اللي سرق منديل سنية] أبقى أنا أستحق ضرب الثبشب!.... }
\end{aligned}
$$

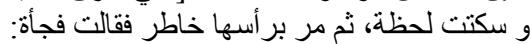

$$
\begin{aligned}
& \text { - يوه... يا ندامة!... نسيت و احد! [...] باللك كمان مين يكون سرق المنديل؟ [...] "سليم"! (ع. ر. 1: 17-18). }
\end{aligned}
$$

- Reanudó sus palabras, añadiendo:

- ¡Si resulta que no es ‘Abduh” [el que robó el pañuelo], merecería que me golpeasen con las zapatillas!

Tras un instante de silencio, se dio cuenta de otra cosa y dijo de repente:

¡Vaya por Dios! ¡Se me ha olvidado uno! [...] ¿Sabes quién puede haber robado también el pañuelo? [...] ¡Salīm!

2. Suave reproche hacia un acto realizado por el interlocutor:

$$
\begin{aligned}
& \text { ـ شوفي يا أبلتي و النبي "ماما" كانت عايزة تعمل للك زيارة النهارده و أنا اللي منعتها!... }
\end{aligned}
$$

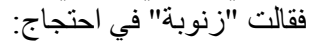

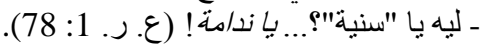

- ¡Mire, le juro que mamá quería hacerle hoy una visita, pero yo se lo he impedido! - ¿Por qué lo has hecho, Saniyya? ¡Por Dios!, protestó Zannūba.

3. Asombro, por parte del hablante, ante un hecho inesperado:

$$
\begin{aligned}
& \text { - و الشيخ "سمحان" يعرف في العنين؟... }
\end{aligned}
$$

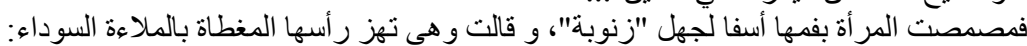

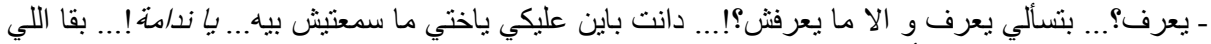

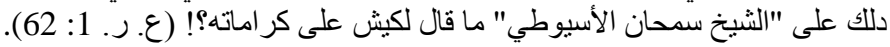

- ¿Pero Šayj Samḥān entiende de ojos?

Haciendo con la boca un gesto que manifiesta su tristeza por la ignorancia de Zannūba, la mujer mueve la cabeza cubierta con el pañuelo negro, afirmando:

- ¿Entender? ¡¿Preguntas si entiende o no?! Se ve, amiga, que no te lo han dicho todo de él. jPor favor! Quien te habló de Šayj Samhān al-Asyūṭ̂̄, ¿̇no te mencionó nada de los milagros que hace?

Los valores semánticos que comportará serán, por lo tanto, tan variados como las mismas situaciones en las que podrá aparecer, de modo que en el discurso "el entorno y la conducta del hablante dan contenido preciso a la proferencia interjectiva”. Esta imprecisión semántica que caracteriza a las interjecciones, su-

Hawādīt al-mašāwīr, Dār al-Šurūq, El Cairo, 2007 y Sālim, 'Alī, 'Afārīt Mișr al-Ŷadīda, en Mu'allafāt 'Alī Sālim, al-Hay’a al-Mișriyya al-'Āmma Li-l-kitāb, El Cairo, 1989, vol. 1, 3-98. De ahora en adelante,

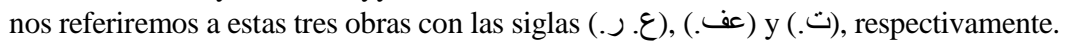

${ }^{9}$ ALONSO-CORTÉS MANTECA, Ángel, "Las construcciones exclamativas. La interjección y las expresiones vocativas”, en Gramática descriptiva de la lengua española, I. BOSQUE y V. DEMONTE (dirs.) (1999) vol. III, Espasa-Calpe, Madrid, 3993-4050, 4026. 
mada a su capacidad de constituir, en líneas generales, enunciados independientes y autosuficientes, ha hecho que la lingüística tradicional vacile a la hora de determinar si tales elementos constituyen una oración completa o si forman, en cambio, uno de sus componentes. Aquellos que vieron en la interjección una de las partes oracionales, se dividieron en dos grupos. Los unos la consideraron como una categoría aparte, puesto que no suele desempeñar ninguna función sintáctica dentro de la oración, mientras que los otros la asimilaron, por ejemplo, al adverbio. Y es que tanto las interjecciones como los adverbios pueden expresar valores actitudinales que impregnan el significado de toda la oración ${ }^{10}$, tal como podemos apreciar en los siguientes enunciados, donde se observa fácilmente cómo los elementos conmutados expresan valores muy cercanos:

$$
\begin{aligned}
& \text { 1- 1 تعرفي و الدتي يا تيزة:.... }
\end{aligned}
$$

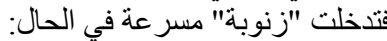

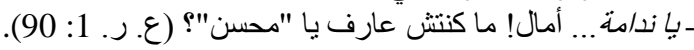

1. ¿Conoce usted a mi madre, tía?

- ¡Por favor! ¡Claro! ¿No lo sabías, Muḥsin?, dijo Zannūba de inmediato.

$$
\begin{aligned}
& \text { 2- تعرفي والدتي يا تيزة؟... } \\
& \text { فتناخلت "زنوبة" مسر عة في في الحال: } \\
& \text { ـ طبعا ... أمال! ما كنتش عارف يا "محسن" }
\end{aligned}
$$

2. ¿Conoce usted a mi madre, tía?

- ¡Naturalmente! ¡Claro! ¿No lo sabías, Muḥsin?, dijo Zannūba de inmediato.

\section{FUNCIÓN PRAGMÁTICA DE LOS ELEMENTOS INTERJECTIVOS}

Tal como acabamos de ver, la información que suelen transmitir las interjecciones no es de carácter conceptual, sino puramente procedimental, esto es, el significado vago que codifica la interjección solo puede estar precisado teniendo en cuenta los elementos que forman parte de la situación del discurso. Ello implica, por consiguiente, que las funciones pragmáticas que pueden desempeñar los elementos interjectivos han de estar íntimamente ligadas a los componentes básicos de la situación del discurso. Como es bien sabido, el proceso de comunicación lingüística requiere la existencia de seis elementos básicos: un código, un emisor, un receptor, un canal, un mensaje físico, que es producto del uso efectivo del código, y un contenido, que se entiende de este mensaje. En el transcurso de la comunicación, el mensaje creado puede responder a cualquiera de estos elementos, de los cuales cada uno determinará una función diferente del lenguaje. Y a pesar de que ningún mensaje suele realizar una sola función, sino que las combina en un orden jerárquico determinado, su naturaleza dependerá de la función que en él predomine. Esta idea

\footnotetext{
${ }^{10}$ LÓPEZ BOBO, María Jesús, La interjección. Aspectos gramaticales, Arco/Libros, Madrid 2002, 19-20.
} 
es la que constituye la base de la famosa teoría de las funciones del lenguaje de Roman Jakobson. Según el célebre lingüista, en torno a cada uno de los seis componentes del proceso comunicativo se alza una función distinta. Así, podremos distinguir las siguientes ${ }^{11}$ :

1. Función emotiva o expresiva, que tendrá como eje el propio emisor.

2. Función conativa, centrada en la figura del receptor.

3. Función fática, basada en el canal.

4. Función poética, enfocada hacia la forma de presentar el mensaje de un modo concreto y no de otro.

5. Función referencial, alrededor del contenido.

6. Función metalingüística, en torno al propio código.

Como hemos visto en el apartado anterior, las interjecciones no pertenecen a la categoría de los elementos significativos que comportan sentido conceptual, por lo que difícilmente podrían realizar las dos últimas funciones a las que acabamos de referir. El dominio de la interjección se limitará, por tanto, a las cuatro primeras funciones mentadas por Jakobson. Así, las interjecciones podrán realizar una función emotiva o expresiva, tal como en el siguiente ejemplo:

ـ و لمح "عبده" أخير ا وحدة "محسن" و انزو اءه في أحد الأركان، فنهض و سار سار حتى اقترب منه كذلك، و و قال:

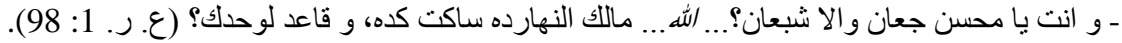

- Finalmente, Abduh se da cuenta de la soledad de Muḥsin y su retiro en un rincón de la casa; acercándose a él, le pregunta:

- Y tú, Muḥsin, ¿tienes hambre o no? ¡Vaya! ¿Por qué estás hoy tan taciturno y solitario?

En este texto, la función semántico-pragmática que realiza la interjección es manifestar el sentimiento de extrañeza que experimenta 'Abduh ante la actitud mostrada por el joven; la función que realiza es, pues, de evidente carácter emotivo o expresivo. En cambio, la función que realiza la interjección en el siguiente segmento es de naturaleza conativa:

- سرح المذيع بعض الثعبير ات المتقبة فوق رأسه، و استعد لبدء التصوير ، باللا 1، 2، 3، داير (ت.: 154).

- El presentador se peina los pocos pelos que aún tiene en la cabeza, preparándose para el rodaje: "Vamos, 1, 2, 3, jacción!”.

El carácter conativo de esta interjección se debe a que el emisor la utiliza para dirigirse al oyente y pedirle que realice una acción concreta. Distinto es el caso en el siguiente segmento:

$$
\begin{aligned}
& \text { ـ المأمور : حمد الله على السلامة يا عزيزي عبده... } \\
& \text { عبده: الله يخليك يا سعادة البيه... }
\end{aligned}
$$

${ }^{11}$ JAKOBSON, Roman, Ensayos de lingüística general (Traducción de Josep M. PUJOL y Jem CABANES), Ariel, Barcelona 1984, 347-395. 


$$
\text { المأمور : هـ... ازى الحال...؟ (عف.: 68)، }
$$

- El Comisario: Bienvenido, querido 'Abduh.

'Abduh: Gracias, señor.

El Comisario: Oye, ¿qué tal te encuentras?,

puesto que lo que hace aquí el emisor es asegurarse de la existencia de la necesaria vinculación psicológica que ha de mediar entre el emisor y el receptor para el eficaz funcionamiento del canal como medio de transporte del mensaje. Dado el interés que tiene el comisario en la interrogación de 'Abduh, intenta asegurarse del establecimiento de dicha vinculación -mediante el uso de la interjección implicada, que garantizaría la atención de su interlocutor-, antes de formular su pregunta. Las interjecciones pueden realizar, finalmente, una función centrada en torno al propio mensaje, esto es, la forma de organizar sus elementos, dando mayor o menor énfasis a alguno de sus componentes, estableciendo el turno de palabras en el diálogo, etc. Dado que en esta ocasión no estamos analizando exclusivamente el lenguaje poético, preferimos dar a la función que realizan las interjecciones centradas en el propio mensaje el calificativo de textual ${ }^{12}$ o discursiva. Así, podemos decir que el elemento interjectivo que aparece en el siguiente segmento realiza una función pragmática de carácter textual:

$$
\begin{aligned}
& \text { ـ الحق عليه... كان يجب أسأله أنا و أعمل الموضوع بتاعي... بس أنا فضلتك على نفسي... آه... انت عارف }
\end{aligned}
$$

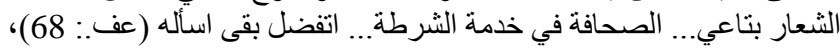

- La culpa es mía. Tenía que haberle entrevistado yo y publicar la entrevista, pero he antepuesto tus intereses a los míos. Sí, señor. Tú conoces bien mi lema. La prensa está al servicio de la policía. Vamos, pregúntale lo que quieras,

puesto que lo que hace es realzar y enfatizar el sentido de la oración que le precede. La función que desempeña la interjección en este caso es, por lo tanto, de evidente carácter textual.

Dada la superioridad numérica de las interjecciones expresivas y su mayor frecuencia de uso con respecto a los otros tres tipos en su conjunto -tal como nos lo corrobora el corpus en el que nos basamos en esta ocasión-, nos limitaremos en lo que queda de nuestro trabajo al análisis de esta categoría de elementos interjectivos, encomendando el estudio de las interjecciones conativas, fáticas y discursivas del árabe dialectal de Egipto a futuras investigaciones.

\section{SINTAXIS DE LOS ELEMENTOS INTERJECTIVOS}

La gramática tradicional, que únicamente basaba sus estudios en la manifestación escrita de la lengua, partía de la palabra como unidad mínima del análisis, conside-

\footnotetext{
${ }^{12}$ EDESO NATALÍAS, Verónica, “Qué hacer con las interjecciones en una clase de ELE”, en Actas del XVII Congreso Internacional de ASELE, Universidad de la Rioja, Logroño 2006, 495-508, 502-506.
} 
rándola como "pilar básico" de toda la investigación lingüística ${ }^{13}$. En función de las características semánticas y formales observadas en las distintas unidades que constituyen el léxico, reclamaba la existencia de diferentes categorías sintácticas: verbo, nombre, adverbio, artículo, conjunción, etc. La aparición del estructuralismo europeo supone un giro significativo en este sentido, puesto que con él se llega a basar el estudio del lenguaje -de forma principal- en la manifestación hablada de la lengua. Así, para poder determinar las diferentes categorías sintácticas existentes, los estudios gramaticales de corte funcionalista exigen que se parta siempre de la comunicación lingüística. Con ello, la palabra deja de ser la unidad básica del análisis y se pasa a adoptar el sintagma como punto de partida del análisis lingüístico, definiéndolo como la "unidad más pequeña y simple que podemos usar -no "mencionar"- al comunicarnos, oralmente o por escrito" ${ }^{14}$. Por otro lado, para que una secuencia lingüística pueda comunicar algo, el hablante la tiene que revestir de modalidad, dado que el oyente solo consigue interpretar adecuadamente la información lingüística transmitida mediante secuencias provistas de cualquiera de las tres modalidades existentes en la lengua: la asertiva, la interrogativa o la exclamativa. De ahí que desde esta perspectiva, el sintagma también se defina como la "unidad mínima que, en solidaridad con un signo entonativo, puede usarse en el acto de comunicación" ${ }^{15}$. Pero como el enunciado no tiene una extensión fija, pudiendo oscilar desde una sola palabra hasta un discurso o una obra literaria completa, la lingüística funcional reserva el término sintagma, como acabamos de señalar, a las secuencias mínimas que pueden erigirse como enunciado. Así, en último término esta unidad lingüística se puede definir "doble pero coincidentemente, como enunciado mínimo posible [...] usado en solidaridad con un signo entonativo" ${ }^{16}$.

Aplicando este criterio a las tradicionales "partes de la oración", tendremos dos grupos bien distintos de unidades lingüísticas; por un lado, el de aquellos elementos que por sí mismos pueden erigirse en enunciados mínimos, y, por el otro, el de aquellas unidades que para formar parte de un enunciado tienen que aglutinarse en torno a uno de los elementos pertenecientes a este primer grupo. Los elementos que por sí solos pueden constituir sintagmas son los que realmente dan soporte a las distintas funciones sintácticas y constituyen así -y con arreglo a sus posibilidades combinatorias- las distintas categorías sintácticas que puede tener una lengua dada. En el árabe dialectal egipcio, pueden funcionar como enunciados mínimos los verbos:

- El Doctor Mansī: ¿ ¿Reunirnos para qué?

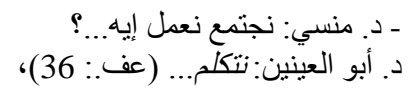

El Doctor Abū al-‘Aynayn: Para hablar...,

${ }^{13}$ GUTIÉRREZ ORDÓÑEZ, Salvador, Principios de sintaxis funcional, Arco/Libros, Madrid 1997, 415.

${ }^{14}$ MARTÍNEZ, José Antonio, Propuesta de gramática funcional, Ediciones Istmo, Madrid 1994, 201.

${ }^{15}$ MARTÍNEZ, José Antonio, Funciones, categorías y transposición, Ediciones Istmo, Madrid 1994, 21.

${ }^{16}$ MARTÍNEZ, José Antonio, Propuesta de gramática..., 98. 
los sustantivos (en los que también se incluyen otros elementos, tales como los pronombres personales de sujeto):

$$
\text { ـ المأمور: [...] الساعة اتناشر بالضبط ييقى مر ثلاث سنين على آخر حادثة... }
$$

- El Comisario: [...] Las doce en punto. Han pasado ya tres años desde el último suceso... Mușțafá: ¡Un milagro!,

los adjetivos:

$$
\begin{aligned}
& \text { ـ ـ المأمور : ليه أعداء.... } \\
& \text { د. سهير: لأ... } \\
& \text { المأمور : متأكدة...؟ (عف : 15)، }
\end{aligned}
$$

- El Comisario: ¿Tiene enemigos?

- La doctora Suhayr: No...

- El Comisario: ¿Segura?,

y adverbios:

- Mușțafá: Una sola pregunta, por favor...

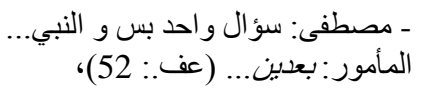

El Comisario: Luego.

Constituyen, por lo tanto, cuatro categorías sintácticas diferentes dentro de esta variedad de árabe. En base a la famosa función de determinación de L. Hjelmslev -que media entre una constante (o sea, elemento nuclear que puede subsistir por sí mismo) y una variable (esto es, elemento adyacente, que desaparece si así lo hace el núcleo) ${ }^{17}$-, se establece, por otro lado, una relación jerárquica dentro de las secuencias en las que confluyen dos o más elementos pertenecientes a cualquiera de estas cuatro categorías. En este caso, el sintagma verbal ocupará la posición más elevada en el escalafón, seguido inmediatamente por el sintagma sustantivo; un peldaño más abajo se encontrará el sintagma adjetivo, que también precede en esta escala al adverbio. Así, el verbo servirá de núcleo para el sustantivo (1); el sustantivo tendrá como adyacente al adjetivo (2) y éste será núcleo del adverbio (3):

1- أظن جعت يا "محسن"... قم خد خيارة اقرشها تصبر بها... من هنا للعشا وقت طويل (ع. ر. ر. 1: 7).

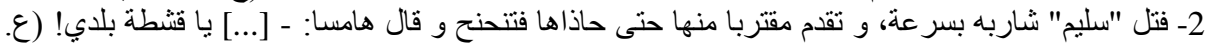

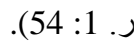

3- دلوقتي أغلبية السنمات بتاعتنا خلاص قفلت، سينما هوليود بقت حاجة تانية، و سينما مصر و سينما ريو [...]

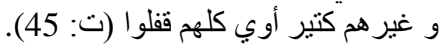

1- Tendrás hambre, Muhssin. Cógete un pepino, para aplacar tu hambre. De aquí a la cena, queda mucho tiempo.

\footnotetext{
${ }^{17}$ Hjelmslev, Louis, Prolegómenos a una teoría del lenguaje, Gredos, Marid 1980, 57.
} 
2- Salīm se trenza el bigote con rapidez, moviéndose hacia ella hasta alcanzarla y entonces le susurra: [...] ¡Oh pedazo de manteca autóctona!

3- La mayor parte de nuestros cines ya han desaparecido. El Cine Hollywood se ha convertido en otra cosa, el Cine de Egipto, El Cine Rio [...] y otros más ya han cerrado.

Esta relación jerárquica solo se ve alterada si interviene un transpositor, esto es, un elemento lingüístico cuya función principal es cambiar la categoría sintáctica de la unidad a la que precede, con el fin de que ésta pueda realizar una función sintáctica diferente a la que en propiedad le viene dada por sus características lingüísticas de origen. Así, mediante el uso de un transpositor, un verbo, p. ej., puede hacer las veces de adyacente de un núcleo de carácter sustantivo (1) o un sustantivo le puede servir de adyacente a otro sintagma de esta misma naturaleza (2):

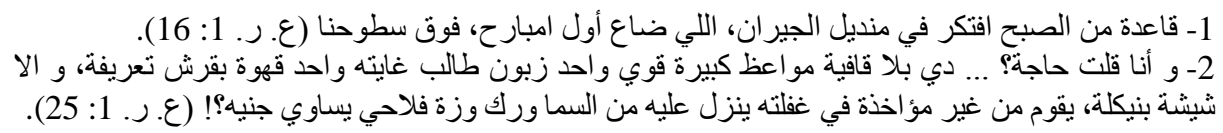

1- Desde la mañana estoy pensando en el pañuelo de los vecinos, el que se perdió anteayer en nuestra azotea.

2- ¿Acaso he dicho yo algo? Estas son, permítame que lo diga, grandes advertencias. A un cliente que haya pedido como mucho un café que solo vale una piastra o una cachimba que no cuesta más que cinco milésimas, ¡¿se le cae desde el cielo, estando él desprevenido, un muslo de una oca campestre que vale una libra?!

De entre las tradicionales “partes de la oración”, los elementos que pueden realizar esta función traspositora son el artículo, la preposición y la conjunción subordinativa. Pero aparte de esta función principal, estas mismas unidades pueden servir también de adyacente de un elemento sintagmático (el artículo, con respecto al sustantivo) o lexicalizar la relación formal que media entre dos componentes que integran un sintagma de carácter exocéntrico (las conjunciones coordinativas) ${ }^{18}$.

Llegados a este punto, cabe plantear la siguiente cuestión: ¿a qué grupo pertenece la interjección? La respuesta a esta pregunta no deja lugar a dudas: las interjecciones son elementos que por sí mismos pueden constituir un sintagma:

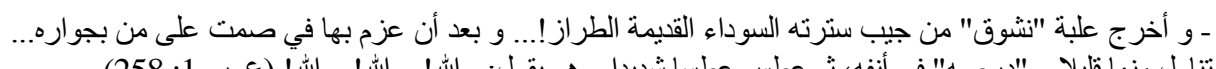

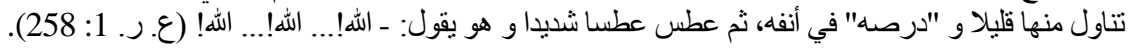

- Sacó del bolsillo de su traje negro y anticuado un bote de rape. Después de invitar en silencio a los que estaban alrededor, cogió un poco para metérselo en la nariz, estornudando luego con fuerza mientras decía: ¡Vaya! ¡Vaya! ¡Vaya!

Están, por lo tanto, al mismo nivel que los verbos, sustantivos, adjetivos y adverbios, con los que, además, pueden yuxtaponerse, como muestra formal de la relación de

${ }^{18}$ MARTÍNEZ, José Antonio, Funciones, categorías..., 13-44. 
equivalencia que media entre ellas y las demás categorías sintácticas que posee el árabe dialectal de Egipto:

$$
\text { ـ ـ أخير ا تقلب "حنفي أفندي" في فر اثهه و قال متبرما: - يا سلام!... تقلق منامنا نص الليل! دا ما كانش سفر! }
$$

- Finalmente, Ḥanafī efendi dio unas vueltas en la cama y dijo molesto: ¡Por Dios! ¡Nos despiertas a medianoche! ¡Dichoso viaje!

$$
\text { ـ أف!... الشغل... الشغل... الثغل! (ع. ر. 2: 107). }
$$

- ¡Uf! ¡El trabajo, el trabajo, el trabajo!

$$
\text { - و استمرت "زنوبة" في استغر ابها: - عجيبة ياختي! اللي يشوفك يقول مش انت! (ع. ر. 1: 6). }
$$

- A Zannūba se le queda la cara de asombro: “iQué extraño, por Dios! ¡Quien te vea no podrá creer que eres tú!”.

Pero siendo así la situación, surge otro interrogante: ¿qué es lo que distingue la interjección con respecto a los demás tipos de sintagmas y qué relaciones sintácticas pueden mediar entre ellos, por un lado, y los elementos interjectivos, por el otro? Para responder a esta pregunta, podemos afirmar que lo primero que diferencia a la interjección frente a todas las demás categorías sintácticas (aparte de no poder combinarse más que con la entonación exclamativa) es su particular forma de significar: mientras que los demás elementos que pueden constituir sintagma son normalmente reducibles a componentes semánticos aún más pequeños (esto es, a un lexema unido a uno o varios morfemas), ninguna interjección admite tal análisis, ni siquiera las interjecciones que aparentemente pudieran tener tales componentes mínimos, so pena de perder el valor interjectivo con el que normalmente se usan:

$$
\text { ـ آه... آه...! انقطع نفسي خلاص... من المشى و اللف يا مسلمين! (ع. ر. 1: 103). }
$$

- ¡Ay! ¡Ay! ¡Ya estoy sin aliento de tanto caminar y caminar, por Dios!

$$
\text { ـ ـ آهات... آهات...! انقطع نفسي خلاص... من المشى و اللف * يا مسلم! }
$$

*_ ¡Ayes! ¡Ayes! ¡Ya estoy sin aliento de tanto caminar y caminar, * musulmán!

Los dos polos que integran los signos interjectivos (el significante y el significado) se relacionan entre sí en bloque, de una forma muy parecida a lo que sucede en el caso de los símbolos.

Otro rasgo diferenciador es la resistencia que muestran los elementos interjectivos a la transposición. Mientras que las restantes cuatro categorías aceptan ser traspuestas las unas en las otras, llegando de esta forma un adjetivo a desempeñar, p. ej., las funciones propias del sustantivo, ninguna interjección puede convertirse en sustantivo, adjetivo, verbo ni adverbio. Este hecho limita enormemente las posibilidades combinatorias de la interjección frente a las demás categorías sintácticas. Así, en tanto que todas las demás categorías pueden combinarse con otras mediante las 
relaciones de determinación (como núcleo o adyacente), constelación (yuxtaponiéndose o coordinándose entre sí) o por interdependencia (transformándose el conjunto en este caso en una nueva categoría) ${ }^{19}$, las interjecciones solo pueden combinarse en el decurso con otros elementos mediante las relaciones que de ninguna forma pueden alterar su categoría sintáctica original. De este modo, la relación de interdependencia, que suele transformar los componentes implicados en una categoría diferente a la que en principio tiene individualmente cada uno de ellos, queda totalmente descartada como posibilidad combinatoria capaz de enlazar las interjecciones con otros elementos dentro de un mismo enunciado. De la relación de constelación, las interjecciones solo eligen la yuxtaposición, resistiéndose a ser trabadas con ningún otro sintagma mediante coordinación:

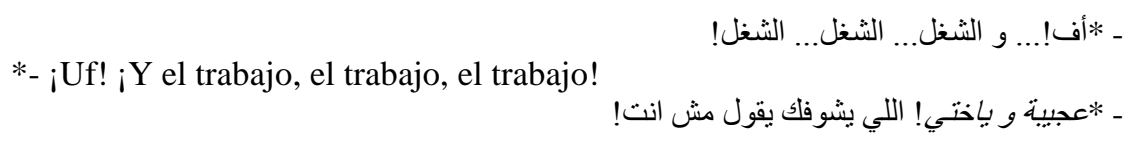

* ¡Qué extraño y por Dios! ¡Quien te vea, no podrá creer que eres tú!

La interjección se niega a coordinarse, ni siquiera, con otros elementos interjectivos: ${ }^{20}$

$$
\text { *- يوه... و يا ندامة!... نسيت واحد! (ع. ر. 1: 17). }
$$

*_ ¡Vaya y por Dios! ¡Se me olvidó uno!

Por yuxtaposición, una unidad interjectiva puede enlazarse no solo con sintagmas simples de carácter sustantivo, verbal, adverbial o adjetival, como hemos tenido la ocasión de ver hasta el momento, sino también con oraciones, sean éstas simples o compuestas:

- ¡Vaya! ¿Qué te ha traído por aquí?

$$
\text { ـ الله...! إيش جابك؟ (ع. ر. 1: 215). }
$$

$$
\text { ـ آه... لو كنت منلك... ما كنت أحلق إلا عند حلاق الأغنيا المعتبرين (ع. ر. 1: 74). }
$$

- ¡Ay! Si estuviera en tu lugar, solo me cortaría el pelo en la peluquería de la gente rica y bien considerada.

Pero hemos de advertir que en estas ocasiones, la interjección no puede quedar nunca subordinada a la predicación del verbo principal que aparece en el enunciado, tal como se pudiera pensar en un primer momento, sino que constituye por sí misma una predicación secundaria. Lo demuestra el hecho de que la interjección puede subsistir sin el elemento oracional, por lo que, en términos de L. Hjelmslev, se trata en este caso, sin lugar a dudas, de una constante (elemento nuclear) y no de una va-

\footnotetext{
${ }^{19}$ GUTIÉRREZ ORDÓÑEZ, Salvador, Principios de sintaxis..., 326-333.

${ }^{20}$ LÓPEZ BOBO, María Jesús, La interjección. Aspectos..., 70.
} 
riable (adyacente) del núcleo verbal. Este hecho lo podemos corroborar mediante la aplicación de la prueba de conmutación por cero a los segmentos oracionales que acompañan a las interjecciones en enunciados como los que acabamos de aducir. En una situación lingüística que cuente con todos los elementos necesarios para capacitar al receptor a entender el valor exacto que el hablante quiere dar a la interjección utilizada, sería totalmente aceptable reducir los anteriores enunciados a los segmentos interjectivos que los encabezan:

- $i$ Vaya!

$-¡$ ¡Ay!

!....

... آ

Así pues, podemos afirmar en este sentido que cuando la interjección concurre en un mismo enunciado con una secuencia de carácter oracional, tendremos siempre como resultado dos predicaciones diferentes, una principal (la que corresponde a la oración) y otra secundaria (correspondiente al elemento interjectivo). En los dos enunciados arriba aducidos, las interjecciones se encargan de informarnos de cierto sentimiento que tiene el hablante con respecto a lo expresado en cada una de las dos oraciones. Su función es crear una predicación secundaria, parafraseable por el verbo "sentir" (conjugado en primera persona del singular), sumado al contenido específico que tiene la interjección en cada caso. De ahí que J. Antonio Martínez atribuya a la interjección en tales supuestos la relación especial que con respecto a la oración suelen guardar los elementos incidentales, de los que afirma, en términos generales, que están "caracterizados (inespecíficamente) en el plano de la expresión por presentarse entre pausas, después de la oración o incrustándose en ella y, lo que importa más, desde el punto de vista de la forma de contenido, como unidades sin función directa ni indirecta con el núcleo oracional” ${ }^{21}$. Esto explica la gran capacidad de movimiento que -cuando las circunstancias sintácticas y semánticas lo permiten- puede desplegar la interjección dentro del enunciado, tal como podemos percibir en el siguiente ejemplo:

$$
\text { ـ ما تنساش إن العيال يا عيني بيتعشموا و بيفتكروا انهم اتعلموا بحق و حقيقي (ت: 165) ، }
$$

- No olvide usted que los chavales, iqué pena!, se hacen ilusiones y creen que han aprendido de verdad,

$$
\text { - با عيني ما تتساش إن العيال بيتعشمو او بيقتكروا انهم اتعلموا بحق و حقيقي، }
$$

- ¡Qué pena!, no olvide usted que los chavales se hacen ilusiones y creen que han aprendido de verdad,

$$
\text { ـ ما تنساش يا عيني إن العيال بيتعشمو او بيفتكروا انهم اتعلمو ا بحق و حقيقي، }
$$

\footnotetext{
${ }^{21}$ MARTÍNEZ, José Antonio, Cuestiones marginadas de gramática española, Ediciones Istmo, Madrid 1994, 275-276.
} 
- No olvide usted, ¡qué pena!, que los chavales se hacen ilusiones y creen que han aprendido de verdad,

el cual podemos seguir reproduciendo hasta agotar todas las posibilidades (ocho en total) que nos puede proporcionar la inserción del elemento interjectivo entre los diferentes constituyentes que componen esta oración.

Cuando la interjección se enlaza con otro elemento en la secuencia mediante la relación de determinación, solo puede hacerlo funcionando como núcleo y nunca como adyacente, debido a la incapacidad que tiene de ser traspuesta a ninguna otra categoría, tal como venimos señalando. En estos supuestos, los únicos elementos que pueden servir de nexo entre la interjección y el segmento al que subordina son las preposiciones (على) (عن) y (عنى). De entre ellas, la que tiene un uso más generalizado es (على):

$$
\text { - يا عمري... ياعمري على دي النهود !... برتقان بلدي لسه على أمه.... ياعمري! (ع. ر. 1: 217). }
$$

- ¡Qué bonitos pechos! ¡Como naranjas aún en sus ramas! ¡Qué hermosura!

- ¡Qué horror de pereza!

$$
\text { - با ساتر على الكسل! (ع. ر. 1: 97). }
$$

$$
\text { - يا سم على سي "عبده"... يا سم! (ع. ر. 1: 8). }
$$

- ¡Qué antipático es ‘Abduh! ¡Qué horror!

$$
\text { - يا سلام على نوقاك و لطفاك يا "سنية"! (ع. ر. 1: 78). }
$$

- ¡Qué amable y educada eres Saniyya!

Las otras dos preposiciones tienen un uso limitado a ciertas interjecciones. En nuestro corpus, la preposición (في) solo aparece en las dos siguientes ocasiones:

$$
\text { ـ الهذهد اليتيم... حسبنا الله و نعم الوكيل في دي الهـهد ... اليتيم... يا عالم... اليتيم... يا ناس (ع. ر. 1: 104). }
$$

- ¡La abubilla huérfana! ¡Maldita sea esta abubilla huérfana, Dios mío! ¡Huérfana, por favor!

$$
\text { ـ علثان إيه؟... سبحان اله في طبعك ... علثان... أفتش... لازم أفتش... مش تسمس إني أفتش؟ (ع. ر. 1: 28). }
$$

- ¡¿Para qué?! ¡Qué extraña es usted! Para inspeccionar, tengo que inspeccionar. ¿No me lo va a permitir usted?

Por su parte, (من) se usa junto con la interjección (آن), para expresar el elemento que causa el malestar que manifiesta el hablante:

- ¡Ay! ¡Ay de ese dichoso muslo de oca!

$$
\text { ـ - آه... آه منه ورك الوزة! (ع. ر. 1: 34). }
$$

En esto se parece a (ي), que junto con esta misma interjección se utiliza para indicar la parte del cuerpo que le duele al hablante: 
ـآهيا ركبي!... من العصر و حياة دقن النبي و أنا داير أجري من الحسينية للقلعة لزينهم للار اسة! (ع. ر. 1: 104).

- ¡Ay de mis rodillas! Toda la tarde, lo juro, he estado caminando entre Hisīniyya, Qal'a y Darrāsa.

En este caso, cuando el hablante siente un dolor que afecta a todo su cuerpo o sufre un malestar generalizado, suele utilizar la expresión (آه ياني):

- Falakī: ¡Ay de mí!

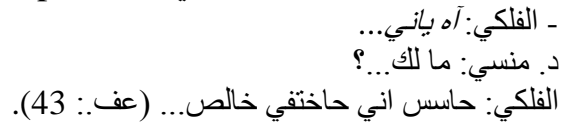

El doctor Mansī: ¿Qué te pasa?

Falakī: Tengo la sensación de que voy a desaparecer del todo.

\section{SEMÁNTICA DE LAS UNIDADES INTERJECTIVAS}

Nuestro objetivo en este apartado es analizar los valores semánticos con los que se emplean las unidades interjectivas de mayor frecuencia de uso en el árabe dialectal de Egipto. Para ello, empezaremos por dividir dichas unidades en los dos grandes grupos que tradicionalmente se suelen distinguir a la hora de estudiar estos elementos lingüísticos: las interjecciones propias y las impropias. Como es bien sabido, esta división se basa en la naturaleza de las funciones semánticas que en la lengua pueden desempeñar las interjecciones; así, mientras que las propias realizan "one function, typical of the category of interjection only, i. e. to express emotions, to attract someone's attention, or to voice an opinion", las impropias, a su vez, "have two functions: that of an interjection and that of a regular lexical item" ${ }^{22}$. Una vez asignados los elementos interjectivos a sus respectivos grupos, procederemos a estudiar los valores desplegados por cada una de las interjecciones de mayor ocurrencia en nuestro corpus.

\subsection{INTERJECCIONES PROPIAS}

En las tres obras en las que basamos este estudio, solo aparecen cuatro interjecciones propias con función semántica de carácter emotivo: (آخص) (إخوه) y (إن) (أن). La última de ellas, que se usa para expresar el malestar que siente el hablante con respecto a uno de los componentes de la situación del discurso, tiene una única ocurrencia (cf. supra). Por su parte, la interjección (يوه) se usa para manifestar que el hablante está molesto; el motivo de este sentimiento habrá que buscarlo en la situación del discurso. En nuestro corpus, hemos observado tres usos. El primero, se realiza cuando por un descuido al hablante le sucede algo que considera negativo. De esta forma, si a una persona se le olvida un hecho importante en relación con el

\footnotetext{
${ }^{22}$ KRYK, Barbara, “The pragmatics of interjections: The case of Polish no”, en Journal of Pargmatics 18 (1992) 193-217, 199-200.
} 
tema del diálogo, surge la posibilidad de usar esta interjección para disculparse por lo ocurrido:

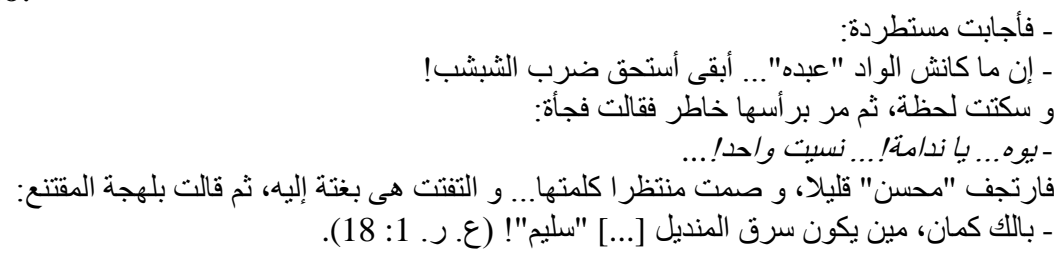

- Reanudó sus palabras, añadiendo:

- ¡Si resulta que no es ‘Abduh”, merecería que me golpeasen con las zapatillas!

Tras un instante de silencio, se dio cuenta de otra cosa y dijo de repente:

- ¡Vaya por Dios! ¡Se me ha olvidado uno!

Muhsin se estremeció un poco, quedando en silencio a la espera de lo que ella le iba a decir. Ella se volvió de repente hacia él, diciendo en un tono convencido:

- ¿Sabes quién puede haber robado también el pañuelo? [...] ¡Salīm!

El segundo uso tiene lugar cuando se descubre una sorpresa desagradable:

$$
\begin{aligned}
& \text { ـ و اخدة باللك يا أبلتي من "الأفندي" أبو شيشة دها!... خبر إيه!... دايما في البلكون بتاعنا! بصي!... كل شوية }
\end{aligned}
$$

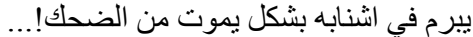

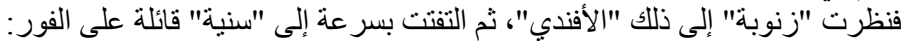

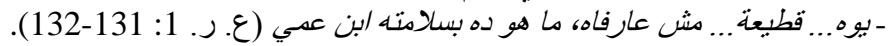

- ¿Ve usted a ese efendi de la cachimba? ¡¿Qué le pasa?! ¡Está siempre mirando a nuestra terraza! ¡Mire usted! No para de trenzarse el bigote de una forma que da risa.

Zannūba miró al efendi, volviéndose rápidamente a Saniyya para decirle:

- ¡Vaya! ¡Qué petardo! ¿No lo conoces? Es mi primo.

Finalmente, esta interjección también se puede emplear para manifestar una ligera protesta por parte del hablante ante los reproches que se le formulan por un acto que anteriormente quería realizar:

$$
\begin{aligned}
& \text { - و تقدمت أجرؤهن، تريد أن تتناول يد الست تقبلها. فانتهرتها الست قائلة بازدر اء: }
\end{aligned}
$$

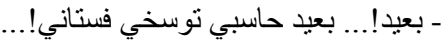

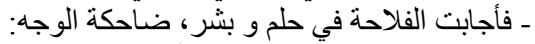

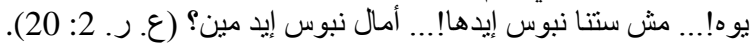

- La más atrevida se adelantó, queriendo besar la mano de la señora, la cual la reprendió con desprecio, diciendo:

- ¡Quita! ¡Quita, que me vas a ensuciar el vestido!

- ¡Vaya! ¿No es usted nuestra señora, a la que debemos besarle la mano? Si no le besamos a usted la mano, ¿a quien se lo haremos?, contestó la campesina risueña, indulgente y con paciencia.

Con (إخص), el hablante manifiesta su desaprobación con respecto a un hecho. Cuando la interjección va seguida por un nombre o un pronombre personal, la des- 
aprobación se dirige hacia la actitud o el comportamiento de la persona a la que hace referencia el nombre o pronombre implicados:

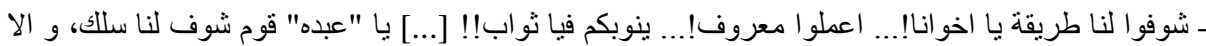

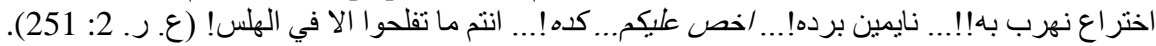

- ¡Buscad una solución, amigos! ¡Por favor! ¡Que Dios os lo pague! [...] ‘Abduh, levántate para buscar un alambre o cualquier invento que nos ayude a escapar. ¡¿Todavía durmiendo?! ¡Qué malos sois! ¡No servís más que para las tonterías!

En nuestro corpus, hemos observado dos usos básicos de esta interjección. En el primero, (إخص) denota un ligero reproche hacia el interlocutor, por haber hecho algo que no es del gusto del hablante o, en otros supuestos, por no hacer, en cambio, una cosa que al hablante le hubiera gustado que se hiciera:

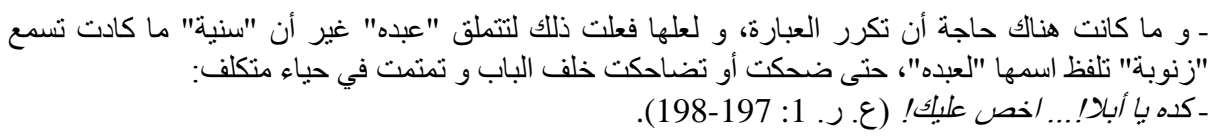

- No tenía por qué repetir esta frase. Pero, tal vez lo hiciera para adular a 'Abduh. En cuanto oyó Saniyya a Zannūba pronunciar su nombre ante 'Abduh, sonrió, o hizo como si sonriera por detrás de la puerta, y refunfuñó con un rubor exagerado:

- ¡¿Así?! ¡Por favor!

En su segundo uso, este elemento interjectivo es empleado por el hablante para incitar a su interlocutor a que realice un acto que en principio se niega a efectuar:

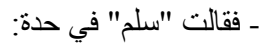

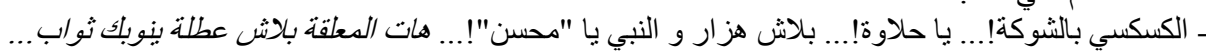

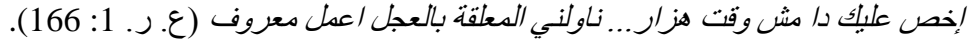

- Dijo Salam con enfado:

- ¡¿Comer el cuscús con tenedor?! ¡Qué bien! ¡Déjate de bromas, Muḥsin! Dame la cuchara, sin demora, por Dios. ¡No seas malo! Este no es momento de bromas. Dame la cuchara rápido, por favor.

La interjección propia más utilizada según los datos de los que disponemos es (آ). En la muestra en la que basamos nuestro estudio, registra dos tipos de funciones semánticas bien diferenciados. El primero es de carácter emotivo, mientras que el segundo es de naturaleza puramente discursiva. Dentro del conjunto de funciones emotivas, esta interjección puede expresar dolor, el cual puede ser físico (1) o moral (2):

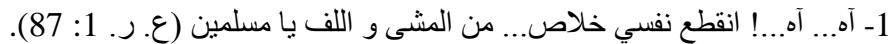

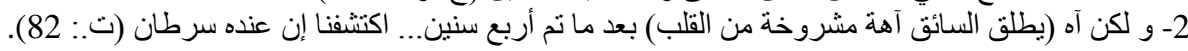

1- ¡Ay! ¡Ay! Ya me he quedado sin aliento de tanto caminar. ¡Por favor! 
2- Pero, ¡ay! (lanza el conductor un "ay” quebrado, que sale del fondo de su corazón), después de cumplir los cuatro años, se le diagnosticó cáncer.

Dentro de esta misma categoría de funciones semánticas, también puede denotar nostalgia:

$$
\begin{aligned}
& \text { ـ أنا أقول لكم عن بحر الغزال... آه بحر الغزال....! السودان! الفئ. }
\end{aligned}
$$

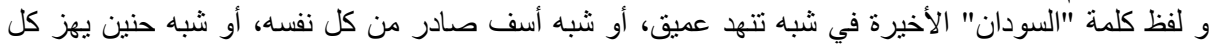

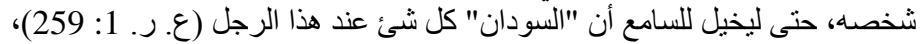

- Os hablaré de Baḥr al-Gazāl, ¡ay de Baḥr al-Gazāl! ¡Sudán!

Profirió la palabra "Sudán" con una suerte de suspiro o una especie tristeza que salía de lo más profundo de su ser, con una nostalgia que lo conmovía de tal forma que quien lo escuchaba se imaginaba que Sudán lo era todo para este hombre.

o una variada gama de otras emociones, que a veces pueden llegar a ser difíciles de definir:

$$
\text { ـ آه يا "محسن" لو كنت صحيح تحبني قد ما أحبك! (ع. ر. 2: 95). }
$$

- ¡Ay, Muḥsin! ¡Si de verdad me quisieras tanto como te quiero yo!

A nivel discursivo, la interjección que ahora nos incumbe puede realizar dos categorías de funciones. La primera contribuye a la organización interna de los datos que proporciona un mismo interlocutor, en tanto que la segunda se vincula más bien con los procedimientos relativos a la construcción de la conversación. En el primer caso, nuestra interjección aparece usada como elemento enfatizador, esto es, para resaltar el segmento al que precede con respecto a los demás componentes del enunciado:

ـ خلاص يا دي الحبايب!... البدنجان سبكته... و البامية قمعتها... و السمك.... آه يا روحي!... قليته قلى يجنن و

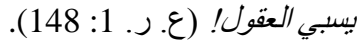

- ¡Ya está, queridos! Las berenjenas, las cociné. La okra, la limpié. Y el pescado, ay, lo he freído de una forma que hechiza.

También pertenece a esta primera categoría el uso que registra este elemento interjectivo como "digresor", formando parte, en este caso, de los marcadores discursivos conocidos con el nombre de "estructuradores de la información”" ${ }^{23}$. Los digresores son elementos lingüísticos que "introducen un comentario lateral en relación con el tópico principal del discurso”" ${ }^{24}$. Es la función que la interjección (آه) realiza cuando expresa una ocurrencia repentina en relación con el tema del que se está hablando; el significado que aporta en tal supuesto se puede parafrasear como "acabo de recordar" o "por cierto":

${ }^{23}$ MARTÍ SÁNCHEZ, Manuel, Los marcadores en español L/E: conectores discursivos y operadores pragámticos, Arco/Libros, Madrid 2008, 56-60.

${ }^{24}$ MARTín ZORRAQUINO, María Antonia y José PORTOLÉS LÁZARO, “Los marcadores del discurso”, en Gramática descriptiva del español, I. BOSQUE y V. DEMONTE (dirs.) (1999) vol. III, Espasa Calpe, Madrid, 4050-4213, 4090. 
ـ "بابا" خرج من بدري زى عادنه يقعد عند "أجزاخانة الجو الي"... آه... شوفي يا أبلتي و النبي "ماما" كانت

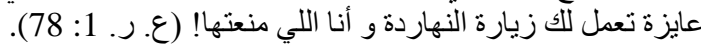

- Papá salió pronto como de costumbre, para sentarse en la farmacia de al-Ŷawwālī. ¡Ah, por cierto, mamá quería hacerle una visita hoy, pero yo se lo he impedido!

En su uso como elemento que contribuye a la construcción de la conversación, se clasificará como un marcador conversacional de carácter metadiscursivo ${ }^{25}$. Como es bien sabido, los marcadores conversacionales contribuyen a estructurar el diálogo y se dividen en cuatro grupos principales: marcadores de modalidad epistémica, marcadores de modalidad deóntica, enfocadores de la alteridad y metadiscursivos conversacionales. La modalidad epistémica se refiere al "grado de compromiso que el hablante tiene en relación con la verdad de la proposición. Este compromiso va del compromiso total del hablante con la verdad de lo enunciado a la neutralidad respecto a esta o incluso a la duda" ${ }^{26}$. Pertenecen a este primer grupo marcadores

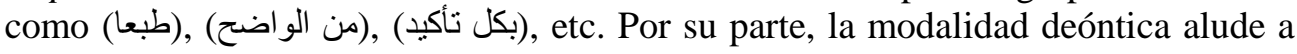
"los modos de actuar sobre la realidad o cambiarla y a los conceptos de permiso, obligación...”" ${ }^{27}$, por lo que entre sus marcadores podemos encontrar expresiones como (مانشي), (خلاص) (مانش مانع), etc. A su vez, los enfocadores de la alteridad son elementos vinculados con las estrategias que indican "la posición que el hablante va adoptando con respecto al interlocutor (amigable, por ejemplo, o distanciada) [...] Estas estrategias se encuentran relacionadas con la llamada cortesía verbal [...], la cual puede ser 'positiva' o 'negativa', según que refuerce la 'imagen positiva' o proteja la 'imagen negativa' de los interlocutores” ${ }^{28}$; realizan esta función elementos lingüísticos como (يا سيدي), (من فضلك), (مام), etc. El último y cuarto grupo, esto es, el de los metadiscursivos conversacionales está integrado por elementos lingüísticos que "forman parte de los procedimientos que utilizan los interlocutores para construir la conversación. Vienen a representar trazos del esfuerzo que realizan los hablantes para formular e ir organizando su discurso" ${ }^{29} \mathrm{e}$ incluye, de esta forma, marcadores como (بس), (هايته), etc. Como hemos señalado anteriormente, la interjección cuyo uso estamos analizando en este apartado pertenece a este último grupo de marcadores conversacionales.

\footnotetext{
${ }^{25}$ MARTÍN ZORRAQUINO, María Antonia y PORTOLÉS LÁZARO, José, “Los marcadores del discurso”..., 4057-4082.

${ }^{26}$ MARTÍ SÁNCHEZ, Manuel, Los marcadores en español..., 77.

${ }^{27}$ MARTÍ SÁNCHEZ, Manuel, Los marcadores en español..., 70.

${ }^{28}$ MARTÍN ZORRAQUINO, María Antonia y José PORTOLÉS LÁZARO, José, “Los marcadores del discurso"..., 4144.

${ }^{29}$ MARTÍN ZORRAQUINO, María Antonia y José PORTOLÉS LÁZARO, José, “Los marcadores del discurso”..., 4191.
} 
La función principal que realiza la interjección (آ) en este sentido es señalar que el mensaje que se acaba de emitir ha sido bien recibido y comprendido por el interlocutor. De ahí que este uso haya sido acuñado con el término de "acuse de recibo"

$$
\begin{aligned}
& \text { ـ كنت عايزة أسألك عن حكاية "الأسطى شخلع" العالمة اللي علمتلك صنعتها... } \\
& \text { فصمت "محسن" قليلا، حتى هدأ جأثنه، ثم قال: }
\end{aligned}
$$

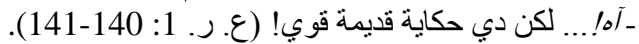

- Quería que me contaras la historia de Šajla‘, la artista que te enseñó la profesión. Muḥsin se quedó en silencio un poco hasta que se tranquilizó y luego dijo:

- ¡Ah! Pero esta es una historia muy vieja.

\subsection{INTERJECCIONES IMPROPIAS}

El mecanismo más frecuente de creación de interjecciones impropias en el árabe dialectal de Egipto se efectúa mediante el uso de la estructura formada por (ب) seguida por un sustantivo, a veces con el posesivo de la primera persona del singular (1) y a veces sin él (2):

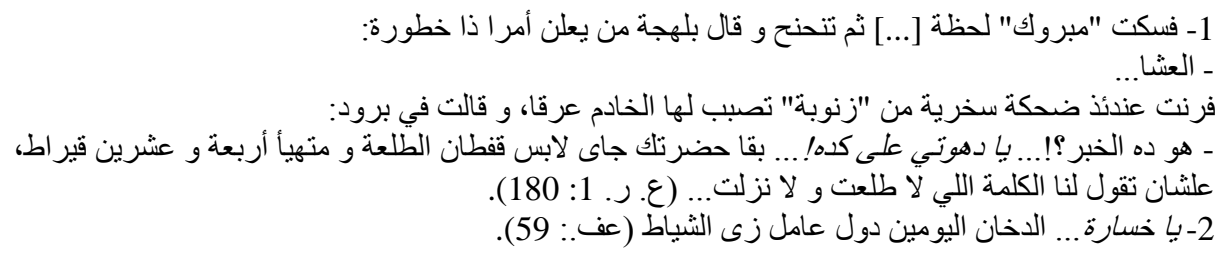

1- Mabrūk se quedó en silencio un instante [...] Carraspeó luego y como quien anunciase un grave noticia dijo:

- La cena...

Sonó entonces una sonrisa irónica de Zannūba, que hizo que el criado sudase abundantemente, y acto seguido le dijo:

- ¡¿Es esta la gran noticia?! ¡Qué desastre! i¿Tú vienes aquí vestido de gala, para decirnos esta palabra que no tiene importancia?!

2- ¡Qué pena! El tabaco de estos días huele a quemado.

Este sustantivo también puede ir con un demostrativo (1) o con un modificador de otra naturaleza (2):

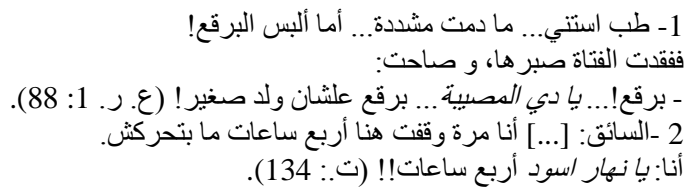

1- Ya que insistes, espérame, entonces, a que me ponga el velo.

Perdiendo la paciencia, la chica gritó:

${ }^{30}$ VÁZQUEZ VEIGA, Nancy, Marcadores discursivos de recepción, Servicio de Publicaciones de la Universidad de Santiago de Compostela, Santiago de Compostela 2003, 193. 
- ¡El velo! ¡Qué desastre! ¡¿El velo para un niño?!

2- El Conductor: [...] Una vez me quedé aquí cuatro horas sin poder moverme.

Yo: ¡Dios mío! ¡Cuatro horas!

Más de la mitad de las interjecciones impropias registradas en la muestra analizada pertenecen a este patrón. La alta frecuencia con la que se usa esta estructura como medio de creación de nuevas unidades interjectivas, ha contribuido a que (يا) se lexicalice como interjección propia en el árabe dialectal de Egipto. Así, en esta variante de árabe el mero uso de (يا), sin el apoyo de ningún sustantivo, sirve, por si solo, como interjección. En tal supuesto, esta voz suele tener la forma ortográfica de (ياه) y denota “asombro” (1) o “nostalgia” (2):

$$
\begin{aligned}
& \text { 1- المأمور : حاجة غريبة إنك تسمع مزيكة هنا...؟ [...] أمال متصور تسمع إيه؟ } \\
& \text { مصطفى: أسمع واحد بيتفقع علقة... مثلا... . }
\end{aligned}
$$

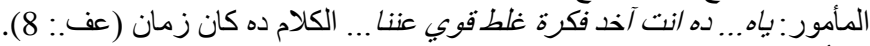

$$
\begin{aligned}
& \text { 2- أنا: إنت بتروح سينما؟ } \\
& \text { السائق: السينما ... ياه ... أنا بقالي مليون سنة ما رحتش سينما (ت .. 41). }
\end{aligned}
$$

1- El Comisario: ¿Es tan extraño escuchar música aquí? [...] ¿Qué imaginabas que ibas a escuchar?

Muștafá: Los gritos de una persona recibiendo una paliza, por ejemplo.

El Comisario: ¡Vaya! ¡Qué idea tan errónea tienes de nosotros! Eso era antes.

2- Yo: ¿Vas al cine?

El Conductor: El cine, ay, llevo ochocientos años sin ir al cine.

Desde el punto de vista semántico, el denominador común en todas las interjecciones creadas por este primer mecanismo es la desaparición de todo contenido vocativo. Incluso en los casos en los que puede surgir la duda, esta afirmación queda corroborada por el hecho de que la concordancia entre la palabra implicada y los elementos del contexto o la situación del discurso queda totalmente inoperativa:

$$
\begin{aligned}
& \text { ــ اللا!... ما شاء الله!... انت لابس بدلة جديدة؟! }
\end{aligned}
$$

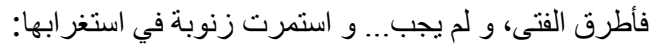

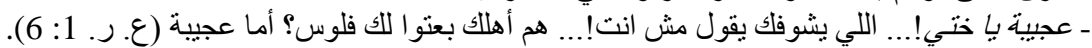

- ¡Vaya! ¡Qué bonito! ¡¿Te has puesto un traje nuevo?!

El joven bajó la cabeza, sin contestar. Siguiendo con su asombro, Zannūba añadió:

- ¡Qué cosa tan extraña! ¡Quien te vea, no creerá que eres tú! ¿Te ha enviado tu familia dinero? ¡Es sorprendente!

Tal como podemos apreciar en el anterior ejemplo, en la situación del discurso en la que es proferida la secuencia (يا ختي) no hay ninguna mujer a la que se pueda interpelar con esta expresión. El único interlocutor que hay en este caso es un chico joven. También apoya el carácter interjectivo de estas expresiones, en detrimento de cualquier otro posible valor apelativo, el hecho de que el sustantivo que constituye el núcleo de la interjección no es extensible mediante el uso de ningún complemen- 
to ajeno a la estructura original. La inserción de cualquier complemento en estos supuestos implica, de forma automática, la pérdida del contenido interjectivo (1) y la aparición de un contenido puramente apelativo (2), tal como podemos comprobar en los siguientes ejemplos:

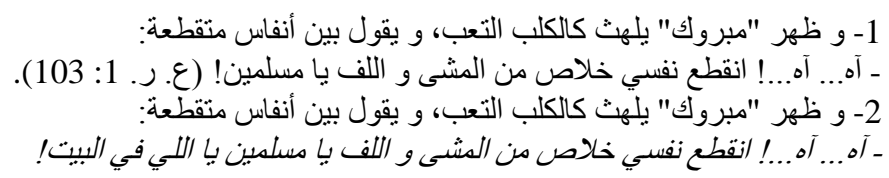

1- Apareció Mabrūk, jadeando como un perro cansado, para decir sin aliento:

- ¡Ay! ¡Ay! ¡Estoy exhausto de caminar tanto y de dar tantas vueltas, por Dios!

2- Apareció Mabrūk, jadeando como un perro cansado, para decir sin aliento:

- ¡Ay! ¡Ay! ¡Estoy exhausto de caminar tanto y de dar tantas vueltas, musulmanes que hay en casa!

No obstante, quizá sea vestigio del contenido apelativo original de estas unidades lingüísticas el hecho de que cuando el sustantivo nuclear tiene sentido colectivo o de plural, la interjección suele denotar "agobio" del hablante, como si toda la secuencia sirviese en este supuesto de llamada de socorro dirigida hacia las personas

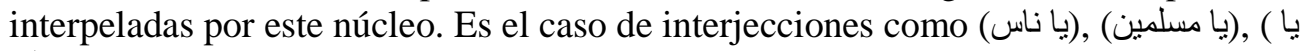
(با هوه) (با خواتي) etc.:

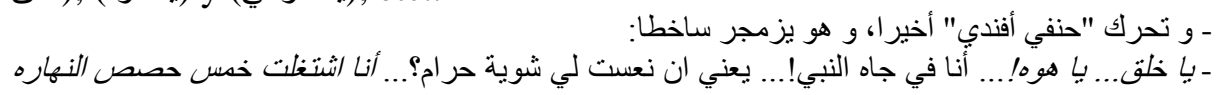

- Por fin, se movió Hanafī efendi, gritando con enfado:

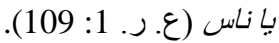

- ¡Por favor! ¡Por Dios! Os lo pido por lo que más queráis. ¿Acaso no tengo derecho a dormir un rato? ¡Hoy he dado cinco clases, Dios mío!

Es llamativo en este sentido el hecho de que mientras la interjección (با خواتي) denota este sentido que acabamos de señalar, el de otras como (با ختي) y (با خويا), esto es, con el núcleo en singular, suele ser el de "extrañeza" o "asombro":

$$
\text { - يا باى!... ياختي ما له عامل زى الأهبل في الزفة! (ع. ر 1: 179). }
$$

- ¡Vaya! ¿Por qué está tan atontado, por Dios?

$$
\text { - يا سلام!... أربعة آلاف جنيه!... أفيال!!... أفيال إيه دول ياخويا؟؟ (ع. ر. 1. 1: 270). }
$$

- ¡Qué raro! ¡Cuatro mil libras! ¡¿Elefantes?! ¡¿Qué elefantes son estos, por favor?!

En muchas otras ocasiones, el valor semántico con el que se usa la interjección es permeable al sentido original del sustantivo que ocupa la posición nuclear de la secuencia. Así, interjecciones como (يا دي المصيية), (با دي الفضيحة) y (با دهوني) denotan la consternación que siente el hablante ante un hecho presente en la situación del discurso:

$$
\text { ـ طباخة؟!... يا دي الفضيحة ياو لاد.... بقا كل ما أنسى تفكروني؟ (ع. ر. 1. 1: 146). }
$$


- ¡¿Cocinera?! ¡Qué escándalo, amigos! ¿Cada vez que se me olvida, me lo volvéis a recordar?

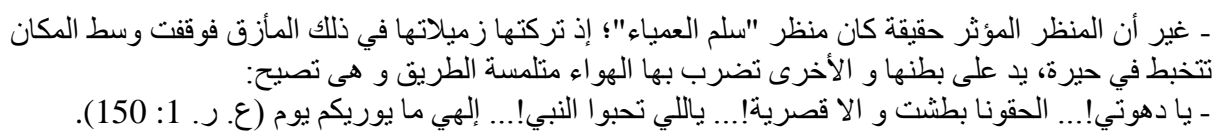

- Sin embargo, lo que realmente impresionaba era el aspecto de Salam, la Ciega. Sus compañeras la dejaron apurada, moviéndose de un lugar a otro perpleja, con una mano en la tripa y la otra dando golpes al aire, buscando el camino mientras gritaba:

- ¡Qué apuro! Denme una fuente o un orinal, por el amor de Dios. ¡Qué Dios no os deje apurados nunca!

En cambio, una unidad como (يا حلاوة) expresará, en principio, sentimientos positivos que tiene el hablante con respecto a la cuestión implicada, aunque en el ejemplo que a continuación aducimos esta interjección se emplee con sentido irónico (el cual surge, precisamente, de este valor positivo original al que nos referimos):

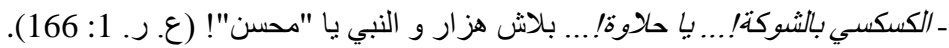

- ¡¿Comer el cuscús con tenedor?! ¡Qué bien! ¡Por favor, déjate de bromas, Muḥsin!

Por su parte, las interjecciones que poseen un grado mayor de lexicalización, se emplean con un valor semántico en el que el sentido lingüístico original del núcleo no se deja ver fácilmente. Es el caso de interjecciones como, p. ej., (يا سلام) y (ع) y (عيني). De este modo, esta última unidad suele denotar un sentimiento de "pena” (1) o de “admiración” (2), que experimenta el hablante en relación con uno de los elementos que integran el contexto o la situación del discurso:

$$
\begin{aligned}
& \text { 1- ما أنا شفت بعيني و لا حدش قال لي أبويا عاش إزاى طول عمره... و شفته يا عبني مات ما عندوش ثمن }
\end{aligned}
$$

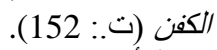

$$
\begin{aligned}
& \text { 2- المأمور : و جهاز التكييف حايركب قريب. }
\end{aligned}
$$

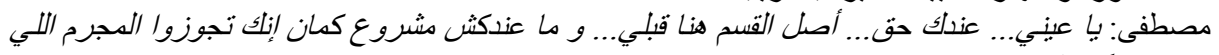

$$
\begin{aligned}
& \text { بيجي عندكم (عف:. 9 9). }
\end{aligned}
$$

1- He visto con mis propios ojos cómo llevó mi padre toda su vida. Lo he visto morir, ¡qué pena!, sin tener con qué comprar la mortaja.

2- El Comisario: Y el aparato de aire acondicionado se instalará pronto.

Muștafá: ¡Vaya! Tienes razón. Es que la comisaría da al sur. ¿No tienes, por casualidad, un proyecto para casar a los criminales que ingresan aquí?

A su vez, (يا سلام) codifica otros dos sentidos, el de “asombro" (1) y el de “agrado” o "gusto" (2), respectivamente:

$$
\begin{aligned}
& \text { 1- يا سلام! دي السودان فيها خير ات عظيمة على كده! (ع. رـ ر. 1: 271). }
\end{aligned}
$$

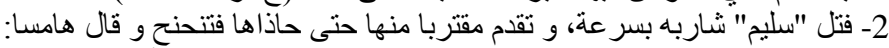

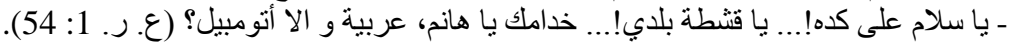


1- ¡Vaya! ¡Sudán está lleno de riquezas, por lo tanto!

2- Salīm se trenzó el bigote con rapidez, se adelantó hasta acercarse a ella y carraspeando le susurró:

- ¡Qué bonito! ¡Manteca autóctona! A sus pies, señora. ¿Un carro o un automóvil?

La aparición de este último valor es muy frecuente como respuesta a una petición formulada por el interlocutor:

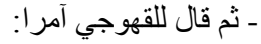

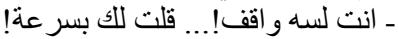

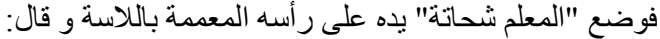

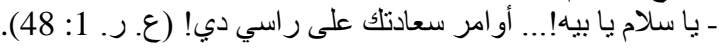

- Le dijo luego al camarero, ordenándolo:

- ¡Aún estás aquí! ¡Te dije rápido!

- ¡Solo esto, señor! ¡Lo que usted mande!, contestó Šiḥāta poniéndose la mano encima de la cabeza, cubierta con un pañuelo.

Como segunda fuente de creación de nuevas interjecciones, el árabe dialectal egipcio echa mano de las expresiones y palabras que pertenecen al legado religioso.

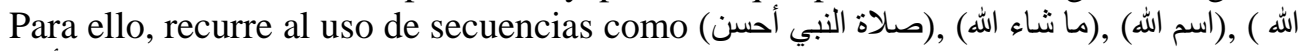
(أكبر), etc. En todos estos casos, es una condición imprescindible para su uso como elementos interjectivos el hecho de que las expresiones y palabras acuñadas hayan culminado un proceso de lexicalización que no permita la permeabilidad del significado original de la secuencia. De esta forma, interjecciones como, p. ej., (النب النبي (أحسن llegan a ser empleadas para denotar los sentimientos de "admiración” e "incredulidad”, respectivamente, que experimenta el hablante en relación con algún elemento presente en el contexto o la situación del discurso:

$$
\text { ـ أما يا أو لاد عليها نهود!... صلاة النبي أحسن!... برتقال حلو صغير على أمه! (ع. ر. 1: 221). }
$$

- ¡Qué pechos tiene, chavales! ¡Qué bonitos! ¡Naranjas bonitas y pequeñas aún en sus ramas!

$$
\begin{aligned}
& \text { ـ نضارة!... اسم الله... تعمل بها إيه؟!... لو كنت نعرف تقرا و تكتب كنا قلنا تقر بها الجر انيل... دا انت حتى } \\
& \text { عليك عينين تندب فيها رصاصة الفعل (ع. ر. 1. 182: 182). }
\end{aligned}
$$

- ¡Gafas! ¡No me digas! ¡¿Para que las necesitas?! Si supieras leer y escribir, diríamos que para que puedas leer el periódico. Pero, tú incluso tienes ojos de lince.

En este apartado, la interjección que en nuestro corpus ha registrado una mayor frecuencia de uso ha sido (اله). Se emplea, en líneas generales, con dos significados básicos: "admiración” hacia un elemento que resulta del agrado del hablante (1) o “asombro”, suscitado por algo que le sorprende (2):

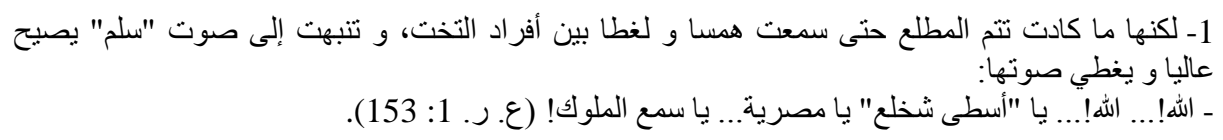




\section{2- و كان "الدكتور فريد" هذا من زبائن "الأوسطى شخلع" المتحمسين و من سميعتها المعجبين، الذين رأو ها كثيرا،

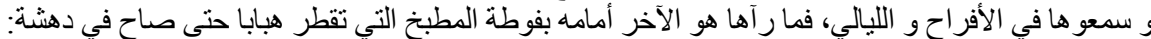

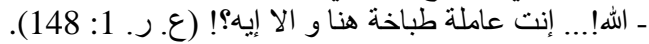

1- Pero apenas hubo terminado el comienzo, cuando escuchó susurro y ruido entre la banda. Se percató, entonces, del grito de Salam, chillando con una voz más fuerte que la suya:

- ¡Qué bonito! ¡Estupendo, señora Šajla‘, la Egipcia, artista de reyes!

2- El doctor Farīd era un admirador entusiasta de Šajla', que la había visto en numerosas ocasiones y la había escuchado en bodas y fiestas. En cuanto la vio delante de él con el mandil lleno de tizne, gritó sorprendido:

- ¡Vaya! ¡¿ Trabajas aquí como cocinera o qué pasa?!

Es frecuente el uso de la interjección con este segundo valor en situaciones en las que el hablante se percata de repente de un hecho del que no se acordaba (1) o también como una respuesta suave a un reproche que le acaba de lanzar su interlocutor (2):

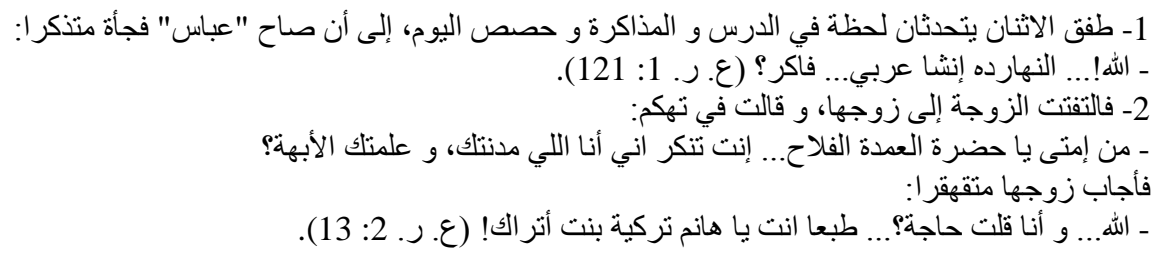

1- Los dos se pusieron a hablar un momento sobre la lección, los estudios y las clases del día, hasta que recordando una cosa, gritó ‘Abbās de repente:

- ¡Por Dios! Hoy tenemos Oratoria Árabe, ¿te acuerdas?

2- La mujer se volvió hacia su marido y con ironía le dijo:

- ¿Desde cuándo señor paleto alcalde niegas que he sido yo quién te he enseñado a ser civilizado y a llevar esta vida de lujo?

- ¡Por favor! ¿Acaso he dicho yo algo? Naturalmente que sí. Tú, señora, eres turca e hija de turcos, contestó el marido, retrocediendo.

Las interjecciones generadas por un mecanismo diferente a los dos aquí señalados, esto es, la lexicalización de expresiones de contenido originalmente vocativo o de carácter religioso, son muy escasas en el árabe dialectal de Egipto. Tanto es así que en la muestra que en esta ocasión nos sirve de base, hemos registrado una única interjección emotiva formada de un modo diferente: (قطيعة). Esta interjección suele denotar la repulsa (1) o indiferencia (2) que siente el hablante con respecto a una persona o un hecho presentes en el contexto o la situación del discurso:

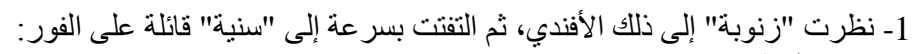

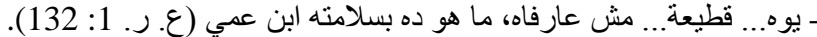

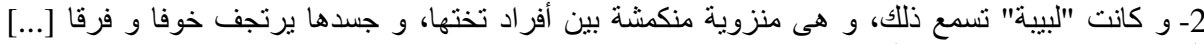

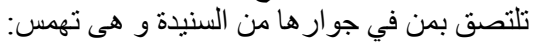

ـ قربي عليا شوية يا "نجية"!... خبيني اعملي معروف!.... امسكيني يا "سلم"... في عرضك [...] 


$$
\begin{aligned}
& \text { فتهـئها "سلم"، و هى أثد منها خوفا، و تهمس لمو لاتها في صوت المزمجر : } \\
& \text { ـ قطيعة!... يعني رايحين يعملوا فينا إيه! (ع. ر. 1. 15 152). }
\end{aligned}
$$

1- Zannūba miró a este efendi, volviéndose rápidamente hacia Saniyya para decirle inmediatamente:

- ¡Vaya! ¡Qué petardo! ¿No lo conoces? Es mi primo.

2- Labība escuchaba esto retirada y escondida entre los miembros de la banda, temblando de miedo y pánico. [...] Se pegaba a quien estaba a su alrededor, susurrando:

-¡Acércate un poco, Naŷiyya! ¡Escóndeme, por favor! ¡Cógeme, Salam, te lo suplico!

[...] Ésta, con un pánico aún superior, intentaba tranquilizar a su jefa, diciéndole con una voz chillona:

- ¡Bah! ¡¿Qué nos van a hacer?!

Se trata, además, de una interjección que se reserva al lenguaje femenino, puesto que los hombres no la suelen usar en su comunicación lingüística diaria.

\section{CONCLUSIONES}

Nuestro objetivo a lo largo de este trabajo ha sido analizar el uso de las interjecciones en el árabe dialectal de Egipto, prestando una especial atención a las de carácter emotivo. Para ello, hemos empezado por estudiar la naturaleza lingüística de las interjecciones en general, llegando a la conclusión de que su contenido semántico es de carácter puramente procedimental, frente a los valores conceptuales que suelen transmitir otros elementos lingüísticos, tales como los sustantivos y adjetivos. La consecuencia de ello es una mayor dependencia de las unidades interjectivas con respecto al contexto y/o la situación del discurso, que desempeñan siempre un papel primordial en la determinación del sentido exacto con el que se emplean dichas unidades. Como un primer acercamiento al análisis de los valores que comportan, hemos estudiado las funciones pragmáticas que las distintas interjecciones pueden realizar en el texto, llegando a la conclusión de que éstas son básicamente cuatro:

1. Función emotiva o expresiva, centrada en el emisor.

2. Función conativa, que gira en torno al receptor.

3. Función fática, basada en el canal.

4. Función textual o discursiva, enfocada en la forma exacta de presentar el mensaje de un modo concreto y no de otro.

Dentro de cada una de dichas funciones generales, la interjección puede expresar una variada gama de valores semánticos.

Analizando las posibilidades combinatorias de las interjecciones, concluimos que se trata de elementos que tienen la capacidad de constituir un sintagma por sí solos. Sin embargo, se diferencian en este sentido frente a verbos, sustantivos, adjetivos y adverbios por su particular forma de significar, que no permite la reducción de sus componentes a elementos semánticos aún más pequeños (los dos polos inte- 
grantes del signo interjectivo se relacionan entre sí en bloque). Por otro lado, las interjecciones se muestran reacias a la transposición o a cualquier otro mecanismo de enlace que pueda afectar a su categoría sintáctica de entrada, hecho que limita enormemente sus posibilidades combinatorias frente a las demás categorías sintácticas. De este modo, la relación de interdependencia queda totalmente descartada, en tanto que de la constelación las interjecciones solo eligen la yuxtaposición, resistiéndose a ser trabadas con ningún otro sintagma mediante coordinación. Cuando la interjección se enlaza en el enunciado con otro elemento mediante la relación de determinación, solo puede hacerlo funcionando como núcleo y nunca como adyacente. En estos supuestos, los únicos nexos posibles son las preposiciones (على), (من) y في).

En el último apartado de nuestro trabajo, nos hemos centrado en el análisis de los valores semánticos con los que se emplean las unidades interjectivas de mayor frecuencia de uso, empezando por dividirlas en los dos grandes grupos que tradicionalmente se suelen distinguir en este sentido: las interjecciones propias y las impropias. De entre las primeras, hemos estudiado los usos de (آل) (إخص) (يوه) y (أف). Respecto a las interjecciones impropias, hemos detectado la existencia de dos mecanismos básicos de creación de nuevas unidades. El primero se efectúa mediante el uso de (با) seguida por un sustantivo (con o sin modificadores), mientras que el segundo se realiza recurriendo a expresiones y palabras que pertenecen al legado religioso. Las interjecciones creadas por el primer mecanismo pueden ser permeables (en una medida u otra, dependiendo siempre del grado de lexicalización alcanzado en cada caso) al sentido original de los elementos que constituyen el núcleo semántico de la secuencia. Para los elementos interjectivos del segundo grupo, es una condición imprescindible haber culminado un proceso de lexicalización que no permita la permeabilidad del significado original para el uso de dichas unidades con valor interjectivo. Las interjecciones generadas por un mecanismo diferente a los dos aquí señalados son tremendamente escasas en el árabe dialectal de Egipto. 